\title{
Manajemen Penyelenggaraan Pendidikan Inklusi pada Lembaga Pendidikan Islam
}

Rahman Tanjung', Yuli Supriani' ${ }^{2}$, Opan Arifudin ${ }^{3}$, Ulfah ${ }^{4}$

${ }^{1}$ STIT Rakeyan Santang Karawang, ${ }^{2}$ IAI Agus Salim Lampung, ${ }^{3,4}$ Universitas Islam Nusantara Bandung E-mail: rahmantanjung1981@gmail.com,yulisupriani30@gmail.com,opan.arifudin@yahoo.com, ismiiulfah@gmail.com,

\section{Article Info \\ Article History \\ Keywords: \\ Management; \\ Inclusive; \\ Education; \\ Islamic.}

Received: 2021-11-20

Revised: 2021-12-15

Published: 2022-01-19

\begin{abstract}
This study describes the study of the management of inclusive education in Islamic educational institutions. The method used in this study uses a library research method or approach, that library research can be interpreted as a series of activities related to the methods of collecting library data, reading and taking notes and processing research materials. The results of this study indicate that inclusive education as an ABK service system is integrated into formal education services. This concept shows that there is only one learning system in inclusive schools, but it is able to accommodate the differences in the learning needs of each individual, in the National school system which so far still tends to apply learning services with "a model of complete learning outcomes together" through classical forms of learning which have an impact on providing less flexibility in application. inclusive education, especially for children with special needs with low mental abilities. Inclusive education for children with special needs has not been understood as an effort to improve the quality of education services, inclusive education tends to be perceived the same as ordinary schools.
\end{abstract}

\begin{tabular}{l}
\hline Artikel Info \\
\hline Sejarah Artikel \\
Diterima: $2021-11-20$ \\
Direvisi: 2021-12-15 \\
Dipublikasi: 2022-01-19
\end{tabular}

Kata kunci: Manajemen; Pendidikan; Inklusi; Islam. Abstrak
Penelitian ini menjelaskan tentang kajian terhadap manajemen penyelenggaraan pendidikan inklusi pada lembaga pendidikan islam. Metode yang digunakan dalam kajian ini menggunakan metode atau pendekatan kepustakaan (library research), bahwa studi pustaka atau kepustakaan dapat diartikan sebagai serangkaian kegiatan yang berkenaan dengan metode pengumpulan data pustaka, membaca dan mencatat serta mengolah bahan penelitian. Hasil penelitian ini menunjukkan bahwa pendidikan inklusi sebagai suatu sistem layanan ABK menyatu dalam layanan pendidikan formal. Konsep ini menunjukkan hanya ada satu sistem pembelajaran dalam sekolah inklusi, tetapi mampu mengakomudasi perbedaan kebutuhan belajar setiap individu, dalam Sistem persekolahan Nasional yang selama ini masih cenderung menerapakan layanan pembelajaran dengan "model ketuntasan hasil belajar bersama" melalui bentuk belajar klasikal berdampak kurang memberikan kefleksibelan penerapan pendidikan inklusi, terutama bagi ABK dengan kondisi kemampuan mental rendah. Pendidikan inklusi bagi anak berkebutuhan khusus belum dipahami sebagai upaya peningkatan kualitas layanan pendidikan, pendidikan inklusi cenderung dipersepsi sama dengan Sekolah biasa.

\section{PENDAHULUAN}

Pendidikan merupakan kebutuhan yang paling vital atau penting untuk manusia agar mendapatkan dan memudahkan kebutuhan hidupnya, dengan pendidikan setiap manusia dapat dengan mudah untuk saling membantu sesama, peran penge-tahuanlah yang dapat membangun komunikasi dengan lingkungan sekitar dan dari hal itu akan terlahir ide, gagasan dan kesadaran (Irwansyah, 2021), maka dari itu tidak ada alasan bagi negara untuk tidak memberikan kesempatan mengenyam pendidikan kepada masyarakat untuk mendapatkan pendidikan yang berkualitas apapun latar belakang warga Negara termasuk mereka yang mempunyai kebutuhan khusus, dalam konteks pendidikan, pemerintah bukan cuma mendahulukan peserta didik yang memiliki kemampuan seperti pelajar pada umumnya dan apalagi memprioritaskan peserta didik golongan darah biru, tetapi harus memprioritaskan pula anak-anak yang orang tuanya berpenghasilan menengah ke bawah, dianggap berkelainan atau memiliki kebutuhan khusus dari anak-anak pada umunya. Hal ini sesuai dengan yang tertuang dalam UUD pasal 31 Ayat 1 "setiap warga negara berhak mendapat pendidikan", namun pada kenyataannya, masih banyak anak-anak di luar sana terutama anak berkebutuhan khusus yang belum atau menyentuh pendidikan, mengapa demikian? Lantas solusi apa yang sudah ditawarkan pemerintah untuk permasalahan seperti itu. 
Kebijakan pendidikan inklusi merupakan sistem penyelenggaraan pendidikan yang mem berikan kesempatan kepada semua peserta didik yang memiliki kelainan dan memiliki potensi kecerdasan dan/atau bakat istimewa untuk mengikuti pendidikan atau pembelajaran dalam lingkungan pendidikan secara bersama-sama dengan peserta didik pada umumnya", hal ini sesuai dengan Permendiknas Nomor 70 Tahun 2009 tentang Pendidikan Inklusi. Pendidikan inklusi merupakan suatu pendekatan pendidikan yang inovatif dan strategis untuk memperluas akses pendidikan bagi semua anak berkebutuhan khusus termasuk anak penyandang cacat, pendidikan inklusif adalah sistem layanan pendidikan yang memberikan kesempatan kepada semua anak belajar bersama-sama di sekolah umum dengan memperhatikan keragaman dan kebutuhan individual, sehingga potensi anak dapat berkembang secara optimal (Direktorat, 2008), sedangkan menurut Dianne Tirocci dan Brandy Reese dalam (Garnida, 2015) bahwa Pendidikan inklusif sebagai tindakan hadir di kelas pendidikan reguler dengan dukungan dan layanan diperlukan untuk berhasil mencapai tujuan pendidikan, penyertaan dalam lingkungan skolastik menguntungkan semua siswa dalam memperoleh kehidupan yang lebih baik, dengan memasukkan semua siswa sebanyak mungkin dalam kelas pendidikan umum atau umum yang dapat dipelajari semua siswa untuk bekerja secara kooperatif, belajar untuk bekerja dengan berbagai jenis orang dan belajar bagaimana membantu orang dalam tugas.

Definisi ini menunjukkan bahwa keberadaan ABK di kelas regular merupakan sesuatu yang penting untuk mencapai tujuan pembelajaran di kelas, keberadaan ABK di kelas inklusif bermanfaat bagi semua anak khususnya dalam pengembangan kompetensi sosial dan peningkatan kecakapan hidup (Arifudin, 2021). Hal ini dapat terwujud manakala ABK bekerja sama secara sinergis dengan anak-anak lainnya dalam menyelesaikan tugas-tugas akademik di sekolah, dalam konteks yang lebih luas, pendidikan inklusi juga dapat dimaknai sebagi satu bentuk reformasi pendidikan yang menekankan sikap anti diskriminasi, perjuangan persamaan hak dan kesempatan, keadilan, dan perluasan akses pendidikan bagi semua, peningkatan mutu pendidikan, upaya strategis dalam menuntaskan wajib belajar 9 tahun serta upaya merubah sikap masyarakat terhadap anak berkebutuhan khusus. Secara formal pendidikan inklusi di Indonesia baru dilaksanakan dalam satu dasawarsa terakhir, namun diyakini bahwa secara alamiah pendidikan inklusi sudah berlangsung sejak lama, hal ini tidak lepas dari faktor-faktor filosofi, sosial, maupun budaya Indonesia yang sangat menghargai dan menjunjung tinggi kebhinekaan atau keberagaman (Arifudin, 2020), faktor-faktor ini tentu dapat menjadi modal dasar bagi pengembangan penyelenggaraan pendidikan inklusi yang sekarang sedang digalakkan.

Upaya pemerintah untuk memberikan layanan pendidikan bagi ABK juga telah dituangkan melalui Peraturan Pemerintah (PP) Nomor 72 tahun 1991 tentang pendidikan luar biasa, Permendiknas Nomor 70 tahun 2009 tentang pendidikan inklusif bagi peserta didik yang memiliki kelainan dan memiliki potensi kecerdasan dan/atau bakat istimewa, serta surat edaran Dirjen Manajemen Pendidikan Dasar dan Menengah Kemendiknas Nomor 380/C.C6/MN/2003 tanggal 20 Januari 2003, yakni setiap kabupaten/kota diwajibkan menyelenggarakan dan mengembangkan pendidikan inklusif di sekurang-kurangnya 4 sekolah yang terdiri dari SD, SMP, SMA, dan SMK, saat ini sudah banyak lembaga pendidikan yang mengembangkan pendidikan inklusif, mengingat cukup banyaknya jumlah ABK khusus di Indonesia. Terdapat 32 ribu sekolah reguler yang menjadi sekolah inklusi diberbagai daerah, data Badan Pusat Statistik (BPS) menunjukkan bahwa dari 1,6 juta $A B K$ di Indonesia, baru $18 \%$ yang sudah mendapatkan layanan pendidikan inklusif. Sekitar 115 ribu ABK bersekolah di Sekolah Luar Biasa (SLB), sedangkan ABK yang bersekolah di sekolah regular pelaksana sekolah inklusif berjumlah sekitar 299 ribu (MINA, 2017). Masih rendahnya jumlah $A B K$ yang mendapatkan layanan ini disebabkan oleh berbagai faktor diantaranya anak yang tidak ingin bersekolah, orang tua yang kurang mendukung pendidikan bagi anaknya, akses sekolah yang cukup jauh dari tempat tinggal ABK, tidak ada Sekolah yang menyelenggarakan pendidikan inklusi dan lain sebagainya.

Kementerian Agama turut dalam pengembangan pendidikan inklusif, Peraturan Menteri Agama (PMA) Nomor 90 Tahun 2013 tentang Penyelenggaraan Pendidikan Madrasah menyebutkan bahwa madrasah wajib menyediakan akses bagi peserta didik berkebutuhan khusus, melalui Direktorat Pendidikan Madrasah Kementerian Agama bertekad mengembangkan pendidikan untuk anak berkebutuhan khusus (difabelitas) atau dikenal dengan pendidikan 
inklusif. Pada tahun 2015 madrasah mulai mencoba menyelenggarakan pendidikan inklusif dengan bantuan Australian Agency for International Development (AusAID), sekolah reguler dengan orientasi inklusif merupakan cara yang paling efektif untuk memerangi sikap diskriminatif, menciptakan masyarakat yang terbuka membangun suatu masyarakat inklusif dan mencapai pendidikan untuk semua. Lebih dari itu sekolah inklusif memberikan pendidikan yang efektif kepada mayoritas anak dalam meningkatkan efisiensi sehingga menekan biaya untuk keseluruhan sistem pendidikan (Stubbs, 2002), termasuk lembaga pendidikan Islam sebagai penyelenggara pendidikan inklusi, sekolah penyelenggara pendidikan inklusif harus mengadopsi pendekatan manajemen dalam rangka mengoptimalkan penyelenggaraan pendidikan dalam rangka mencapai tujuan pendidikan (Mayasari, 2021). Secara umum bahwa lembaga pendidikan inklusi adalah sekolah yang menyediakan layanan pendidikan bagi semua peserta didik biasa maupun peserta didik yang berkebutuhan khusus di kelas yang sama, sekolah penyelenggara pendidikan inklusif merupakan tempat pendidikan untuk Anak Berkebutuhan Khusus untuk mendapat perlakuan secara proporsional dari semua unsur yang terlibat dalam penyelenggaraaan pendidikan. Konsekuensi dari kondisi sekolah penyelenggara pendidikan inklusif menuntut adanya penyesuaian strategi pembelajaran dalam upaya melaksanakan kurikulum yang telah disahkan secara nasional (Budiyanto, 2012).

\section{METODE PENELITIAN}

Sesuai dengan karakteristik masalah yang diangkat dalam penelitan ini maka menggunakan metode riset kualitatif yaitu menekankan analisanya pada data deskriptif berupa kata-kata tertulis yang diamati, pendekatan kualitatif penulis gunakan untuk menganalisis kajian terhadap manajemen penyelenggaraan pendidikan inklusi pada lembaga pendidikan islam, maka dengan sendirinya penganalisaan data ini lebih difokuskan pada Penelitian Kepustakaan (Library Research) yakni dengan membaca, menelaah dan mengkaji buku-buku dan sumber tulisan yang erat kaitannya dengan masalah yang dibahas. Metode yang digunakan dalam kajian ini menggunakan metode atau pendekatan kepustakaan (library research), menurut Zed dalam (Rahayu, 2020) bahwa studi pustaka atau kepustakaan dapat diartikan sebagai serangkaian kegiatan yang berkenaan dengan metode pengumpulan data pustaka, membaca dan mencatat serta mengolah bahan penelitian.

Jenis penelitian ini adalah penelitian kualitatif, menurut Ibnu dalam (Arifudin, 2019) penelitian kualitatif adalah suatu penelitian yang datanya dinyatakan dalam bentuk verbal dan dianalisis tanpa menggunakan teknik statistik, berdasarkan beberapa definisi penelitian kualitatif di atas dapat disimpulkan bahwa penelitian kualitatif adalah suatu penelitian yang datanya dinyatakan dalam bentuk verbal, tidak menggunakan angka dan analisisnya tanpa menggunakan teknik statistik.

1. Objek Penelitian

Dalam penelitian ini objek penelitian terdiri dari 2 (dua) yaitu objek formal dan objek material (Arifudin, 2018), objek formal dalam penelitian ini berupa data yaitu data yang berhubungan dengan tinjauan kritis kajian terhadap manajemen penyelenggaraan pendidikan inklusi pada lembaga pendidikan islam, sedangkan objek materialnya berupa sumber data, dalam hal ini adalah tinjauan kritis kajian terhadap manajemen penyelenggaraan pendidikan inklusi pada lembaga pendidikan islam.

2. Waktu Penelitian

Penelitian ini dilaksanakan pada bulan Oktober sampai dengan November tahun 2021.

3. Teknik Pengumpulan Data

Pengumpulan data yang dilakukan dengan menggunakan teknik dokumentasi yaitu mengadakan survey bahan kepustakaan untuk mengumpulkan bahan-bahan dan studi literatur yakni mempelajari bahan-bahan yang berkaitan dengan objek penelitian. Teknik pengumpulan data menurut (Bahri, 2021) mengemukakan bahwa merupakan langkah yang paling strategis dalam penelitian karena tujuan untama dari penelitian adalah mendapatkan data. Terdapat beberapa cara atau teknik dalam mengumpulkan data diantaranya adalah observasi dan dokumentasi, sumber data yang digunakan dalam penelitian ini mencakup data primer dan sekunder. Menurut (Hanafiah, 2021) bahwa data primer adalah data yang dikumpulkan langsung dari individu-individu yang diselidiki atau data tangan pertama, sedangkan data sekunder adalah data yang ada dalam pustaka-pustaka. Data primer dalam penelitian ini adalah buku-buku terkait tinjauan kritis kajian terhadap manajemen penyelenggaraan pendidikan inklusi pada 
lembaga pendidikan islam, dan data sekunder didapatkan dari jurnal-jurnal baik nasional maupun internasional.

4. Alat Pengumpulan Data

Dalam penelitian ini penulis akan menggunakan metode dokumentasi sebagai alat untuk pengumpul data karena penelitian ini adalah penelitian kepustakaan, dengan kata lain menurut (Juhji, 2020) bahwa teknik ini digunakan untuk menghimpun data-data dari sumber primer maupun sekunder.

5. Teknik Analisis Data

Analisis data tidak saja dilakukan setelah data terkumpul tetapi sejak tahap pengumpulan data proses analisis telah dilakukan, penulis menggunakan strategi analisis "kualitatif", strategi ini dimaksudkan bahwa analisis bertolak dari data-data dan bermuara pada kesimpulan-kesimpulan umum, berdasarkan pada strategi analisis data ini dalam rangka membentuk kesimpulan-kesimpulan umum analisis dapat dilakukan menggunakan kerangka pikir "induktif". Menurut (Sugiyono, 2015) bahwa metode pembahasan menggunakan metode deskriptif-analisis yaitu menjelaskan serta mengelaborasi ide-ide utama yang berkenaan dengan topik yang dibahas, kemudian menyajikannya secara kritis melalui sumber-sumber pustaka primer maupun skunder yang berkaitan dengan tema.

6. Prosedur Penelitian

Data pada penelitian ini dicatat, dipilih dan kemudian diklasifikasikan sesuai dengan kategori yang ada, pendekatan yang digunakan adalah pendekatan deskriptif analitis, menurut (Nasser, 2021) bahwa deskriptif analitis (descriptive of analyze research) yaitu pencarian berupa fakta hasil dari ide pemikiran seseorang melalui cara mencari, menganalisis, membuat interpretasi serta melakukan generalisasi terhadap hasil penelitian yang dilakukan. Prosedur penelitian ini adalah untuk menghasilkan data deskriptif yang berupa data tertulis setelah melakukan analisis pemikiran (content analyze) dari suatu teks, setelah penulis mengumpulkan bahan-bahan yang berhubungan dengan masalah yang akan di bahas dalam penelitian ini, kemudian penulis menganalisis dan menarasikan untuk diambil kesimpulan.

\section{HASIL DAN PEMBAHASAN}

Dalam pembahasan ini akan dibahas tentang keberadaan pendidikan inklusi dalam konteks persekolahan nasional, permasalahan yang dialami sekolah-sekolah yang mengadakan pendidikan inklusi, penyelenggaraan Sekolah inklusi pada Lembaga Pendidikan islam, dan solusi serta kebijakan untuk tindak lanjut dari permasalahan-permasalahan yang dialami sekolah-sekolah dalam mengadakan pendidikan inklusi.

\section{Keberadaan Pendidikan Inklusi dalam Konteks Persekolahan Nasional}

Undang-undang Nomor 20 Tahun 2003 tentang Sistem Pendidikan Nasional yang didalamnya mengamanatkan tujuan dan fungsi pendidikan, termasuk sistem pendidikan untuk Anak Berkebutuhan Khusus (ABK), dari undang-undang ini kemudian hadir berbagai peraturan tentang pendidikan salah satunya Peraturan Pemerintah Nomor 19 Tahun 2005 tentang Standar Nasional Pendidikan yang mencakup delapan (8) standar. Inti kebijakan ini adanya sistem pendidikan yang bersifat umum sebagai tolak ukur minimal kulaitas layanan pendidikan, implementasi dari kebijakan tersebut diharapakan setiap layanan pendidikan dapat mencapai ketuntasan minimal, secara konseptual pendidikan inklusi merupakan sistem layanan Pendidikan Luar Biasa (PLB) yang mempersyaratkan agar semua ABK dilayanai di sekolah umum terdekat bersama teman seusianya, dalam pendidikan inklusi menempatkan ABK tingkat ringan, sedang dan berat secara penuh di kelas biasa (Kustawan, 2013).

Secara umum menurut (Tarmansyah, 2007) bahwa pendidikan inklusi dapat dikelompokan sesuai dengan konsep pendidikan Nasional yaitu: pertama, inklusi sebagai pendidikan yang memberikan kesempatan yang adil kepada semua siswa untuk bisa mengakses pendidikan tanpa membedakan gender, etnik, status sosial dan kebutuhan khusus (kemampuan) pada semua level/jenjang pendidikan. Kedua, dalam sekolah inklusi menerapkan model multi input artinya tidak mengenal penolakan murid, kondisi ini tentu berbeda dengan sistem seleksi siswa baru dalam persekolahan yang saat ini masih cenderung menggunakan seleksi peringkat nilai hasil kelulusan. Ketiga, program kurikulum dalam pendidikan inklusi berbasis kepada anak, dalam hal ini tentu disesuaikan dengan kebutuh ABK, penyelenggaraan pembelajaran dilaksanakan dalam kelas bersama-sama siswa regular dan 
ABK. Keempat, sistem evaluasi bersifat fair atau adil disesuaikan dengan kemampuan siswa, bagi siswa yang mampu mengikuti evaluasi regular dievaluasi sesuai sistem evaluasi reguler, dengan memodifikasi instrumen jika diperlukan, namun bagi siswa dengan program terindividualisasikan (PPI) maka evaluasi disesuaikan dengan PPI-nya, asil evaluasi selain dikonfersi dalam bentuk kuantitatif dan berbentuk deskriptif, yang menggambarkan pencapaian kinerja, khusus untuk $A B K$ dengan kategori sedang dan berat hasil evaluasi bukan sebagai indikotor kenaikan jenjang pendidikan lanjut tetapi sebagai tolak ukur peningkatan potensi kemandirian untuk kehidupan di lingkungannya.

\section{Permasalahan yang dialami Sekolah- Sekolah yang Mengadakan Pendidikan Inklusi}

Sekalipun perkembangan pendidikan inklusi di negara kita cukup menggembirakan dan mendapat apresiasi dan antusiasme dari berbagai kalangan, terutama para praktisi pendidikan namun sejauh ini dalam tataran implementasinya di lapangan masih dihadapkan kepada berbagai isu dan permasalahan.

Menurut (Sunardi., 2009) mengemukakan hasil penelitian terhadap 12 sekolah penyelenggara inklusi, secara umum saat ini terdapat lima kelompok issue dan permasalahan pendidikan inklusi di tingkat sekolah yang perlu dicermati dan diantisipasi agar tidak menghambat, implementasinya tidak bisa atau bahkan menggagalkan pendidikan inklusi itu sendiri yaitu: pemahaman dan implementasinya, kebijakan sekolah, proses pembelajaran, kondisi guru, dan support system. Salah satu bagian penting dari support system adalah tentang penyiapan anak, selanjutnya berdasar isu-isu tersebut permasalahan yang dihadapi adalah sebagai berikut:

a) Pemahaman inklusi dan implikasinya

1) Pendidikan inklusi bagi anak berkelainan belum dipahami sebagai upaya peningkatan kualitas layanan pendidikan, masih dipahami sebagai upaya memasukkan disabled children ke sekolah regular dalam rangka give education right dan kemudahan access education and againt discrimination.

2) Pendidikan inklusi cenderung dipersepsi sama dengan integrasi sehingga masih ditemukan pendapat bahwa anak harus menyesuaikan dengan sistem sekolah.

3) Secara implementasinya guru cenderung belum mampu bersikap proaktif dan ramah terhadap semua anak sehingga menimbulkan komplain orang tua.

b) Kebijakan sekolah

1) Sekalipun sudah didukung dengan visi yang cukup jelas menerima semua jenis anak berkebutuhan khusus, sebagian sudah memiliki guru khusus anak berkebutuhan mempunyai catatan hambatan belajar pada masing-masing anak berkebutuhan khusus dan kebebasan guru kelas dan guru khusus untuk mengimplementasikan pembelajaran yang lebih kreatif dan inovatif, namun cenderung belum didukung dengan koordinasi dengan tenaga profesional, organisasi atau institusi terkait.

2) Masih terdapat kebijakan yang kurang tepat yaitu guru kelas tidak memiliki tangung jawab pada kemajuan belajar anak berkebutuhan khusus serta keharusan orang tua anak berkebutuhan khusus dalam penyediaan guru khusus.

c) Proses pembelajaran

1) Proses pembelajaran belum dilaksanakan dalam bentuk team teaching, tidak dilakukan secara terkoordinasi.

2) Guru cenderung masih mengalami kesulitan dalam merumusakan flexible curriculum, pembuatan IEP (Individualized Educational Program) dan dalam menentukan tujuan, materi, dan metode pembelajaran.

3) Masih terjadi kesalahan praktek bahwa target kurikulum ABK sama dengan siswa lainnya serta anggapan bahwa siswa ABK tidak memiliki kemampuan yang cukup untuk menguasai materi belajar.

4) Karena keterbatasan fasilitas sekolah, pelaksanaan pembelajaran belum menggunakan media, resource, dan lingkungan yang beragam sesuai kebutuhan anak.

d) Kondisi guru

1) Belum didukung dengan kualitas guru yang memadai, guru kelas masih dipandang not sensitive and proactive yet to the special needs children. 
2) Keberadaan guru khusus masih dinilai belum sensitif dan proaktif terhadap permasalahan yang dihadapi ABK.

e) Sistem dukungan

1) Belum didukung dengan sistem dukungan yang memadai peran orang tua, sekolah khusus, tenaga ahli, perguruan tinggi-LPTK PLB dan pemerintah masih dinilai minimal. Sementara itu fasilitas sekolah juga masih terbatas.

2) Keterlibatan orang tua sebagai salah satu kunci keberhasilan dalam pendidikan inklusi, belum terbina dengan baik dampaknya orang tua sering bersikap kurang peduli dan realistik terhadap anaknya.

\section{Penyelenggaraan Sekolah Inklusi pada Lembaga Pendidikan Islam}

Pembelajaran adalah suatu kegiatan yang dilakukan secara sadar dan sengaja (Sofyan, 2020). Pembelajaran secara umum mempunyai tujuan untuk membantu peserta didik agar memperoleh berbagai pengalaman dan dengan pengalaman itu tingkah laku peserta didik bertambah, baik kuantitas maupun kualitas (Na'im, 2021), tingkah laku yang dimaksud meliputi pengetahuan, keterampilan dan nilai atau norma yang berfungsi sebagai pengendali sikap dan perilaku (Darsono, 2000).

Sedangkan dalam pembelajaran inklusi diselenggarakan dengan tujuan:

a) Memberikan kesempatan yang seluasluasnya kepada semua anak (termasuk Anak Berkebutuhan Khusus) mendapatkan pendidikan yang layak sesuai dengan kebutuhannya.

b) Membantu mempercepat program wajib belajar pendidikan dasar.

c) Membantu meningkatkan mutu pendidikan dasar dan menengah dengan menekan angka tinggal kelas dan putus sekola.

d) Menciptakan sistem pendidikan yang menghargai keanekaragaman, tidak diskriminatif serta ramah terhadap pembelajaran (Direktorat, 2007).

Pada tahap ini guru melaksanakan program pembelajaran serta pengorganisasian siswa berkelainan di kelas reguler sesuai dengan rancangan yang telah disusun (Tanjung, 2020), pelaksanaan pembelajaran dapat dilakukan melalui individualisasi pengajaran artinya; anak belajar pada topik yang sama, waktu dan ruang yang sama, namun dengan materi yang berbedabeda. Cara lain proses pembelajaran dilakukan secara individual artinya anak diberi layanan secara individual dengan bantuan guru khusus (Nadeak, 2020), dalam proses pembelajaran inklusi dapat dilakukan jika dianggap memiliki rentang materi/keterampilan yang sifatnya mendasar (prerequisit). Proses layanan ini dapat dilakukan secara terpisah atau masih di kelas tersebut sepanjang tidak mengganggu situasi belajar secara keseluruhan (Budiyanto, 2012).

Pelaksanaan pembelajaran merupakan implementasi dari RPP (Hasbi, 2021), pelaksanaan pembelajaran meliputi kegiatan pendahuluan, kegiatan inti dan kegiatan penutup.

a) Kegiatan pendahuluan, dalam kegiatan pendahuluan guru harus melakukan beberapa hal sebagai berikut:

1) Menyiapkan peserta didik secara psikis dan fisik untuk mengikuti proses pembelajaran.

2) Mengajukan pertanyaan-pertanyaan yang mengaitkan pengetahuan sebelumnya dengan materi yang akan dipelajari.

3) Menjelaskan tujuan pembelajaran atau kompetensi dasar yang akan dicapai.

4) Menyampaikan cakupan materi dan penjelasan uraian kegiatan sesuai silabus.

b) Kegiatan inti, dalam pelaksanaan kegiatan inti merupakan proses pembelajaran untuk mencapai KD yang dilakukan secara interaktif, inspiratif, menyenangkan, menantang, memotivasi peserta didik untuk berpartisipasi aktif serta memberikan ruang yang cukup bagi prakarsa, kreativitas, dan kemandirian sesuai dengan bakat, minat dan perkembangan fisik serta psikologis peserta didik, kegiatan inti menggunakan metode yang disesuaikan dengan karakteristik peserta didik dan mata pelajaran, yang dapat meliputi proses eksplorasi, elaborasi, dan konfirmasi.

c) Kegiatan penutup, dalam kegiatan penutup guru diharapkan dapat melakukan:

1) Bersama-sama dengan peserta didik dan/atau sendiri membuat rangkuman/simpulan pelajaran.

2) Melakukan penilaian dan/atau refleksi terhadap kegiatan yang sudah dilaksanakan secara konsisten dan terprogram. 
3) Memberikan umpan balik terhadap proses dan hasil pembelajaran.

4) Merencanakan kegiatan tindak lanjut dalam bentuk pembelajaran remidi, program pengayaan, layanan konseling dan/atau memberikan tugas, baik tugas individual maupun kelompok sesuai dengan hasil belajar peserta didik.

5) Menyampaikan rencana pembelajaran pada pertemuan berikutnya (Machali, 2010).

Dalam penyelenggaraan kegiatan organisasi, pemimpin memiliki peran yang sangat besar dalam berjalannya setiap penyelenggaraan organisasi (Febrianty, 2020), kepala Madrasah selaku ujung tombak pelaksanaan madrasah inklusi sangat membutuhkan regulasi yang jelas dari Kemenag sehingga pelaksanaan pendidikan inklusif madrasah benar-benar dapat berjalan optimal. Sementara kemitraan dengan dinas pendidikan yang notabene telah memiliki sekolah inklusi harus dibangun dalam proses pembelajaran, ABK ditempatkan dikelas bersama dengan anak-anak regular satu kelas dengan anak-anak regular tapi tingkat kompetensinya yang paling rendah dibanding yang lain. Hal ini sejalan yang dikatakan (Agbayewa, 2011), bahwa pengelompokkan siswa berdasarkan kemampuan kognitif dapat memberikan keuntungan yakni meningkatan prestasi siswa, memudahkan guru dalam mengajar di kelas, memudahkan guru untuk mengendalikan proses pemberian instruksi, dan memudahkan guru memberikan penguatan kepada siswa yang berprestasi tinggi dan berprestasi rendah, siswa yang berprestasi rendah merasa lebih nyaman ketika berada bersama teman-teman yang memiliki kemampuan setara, siswa yang berprestasi tinggi juga dapat saling menjaga dan mendukung minat mereka, siswa bisa saling menghargai dan berpartisipasi dalam kerja kelompok antar siswa, membantu guru dalam menyesuaikan bahan dan metode pengajaran yang sesuai dengan kebutuhan dan tingkat siswa, pemanfaatan waktu, ruang dan bahan bagi siswa dapat menjadi lebih optimal, dan siswa dapat bekerja secara cepat atau lambat sesuai dengan tingkat kemampuan kelas mereka.

\section{Solusi Serta Kebijakan untuk Tindak Lanjut dari Permasalahan-Permasalahan}

yang dialami Sekolah-Sekolah dalam Mengadakan Pendidikan Inklusi

a) Hasil

Permasalahan pelaksanaan pendidikan inklusi berdasarkan kendala-kendala yang dipaparkan di atas maka dapat dijelaskan alternatif kebijakan dengan pendekatan teori rasional komprehensif, pendekatan teori ini dapat memberikan alternatif dengan melakukan pemilihan secara nalar komperhensif tentang perlunya mengambil arah kebijakan. Teori rasional komperhensif memberi batasan kualifikasi mengenai pembuatan keputusan yakni ;

1) Pembuat keputusan individual atau kolektif harus mengindentifikasikan masalah kebijakan yang diterima sebagai konsesus oleh semua pelaku kebijakan

2) Harus mengenditifikasikan dan mengurutkan secara konsiten tujuan dan sasaran yang pencapaiannya mencerminkan pemecahan masalah.

3) Mengidentifikasikan semua pilihan kebijakan yang dapat memberi kontribusi terhadap pencapaian masing-masing.

4) Pembuat keputusan harus meramalkan semua konsekuensi yang akan dihasilkan oleh seleksi setiap alternatif.

5) Pembuat keputusan harus memilih alternatif yang memaksimalkan tercapainya tujuan.

Teori rational komperhensif, dapat memberikan alternatif pemecahan masalah meskipun ada hal yang kurang dalam pengambilan teori ini, bahwa akan terjadi pertentangan antara politik dan birokrasi dalam pengambilan putusan bersama (Bairizki, 2021). Pengambilan teori ini akan memberikan dampak ganda, jika pelaksana kebijakan tidak bisa menerima kebijakan ini.

Alternatif yang diberikan adalah ;

1) Alternatif A; Pendidikan guru secara berkelanjutan tentang konsep pendidikan inklusi dan peran dinas pendidikan

2) Alternatif B; Sosialisasi pemerintah, dalam merubah budaya masyarakat tentang pola pikir tentang pendidikan inklusi

3) Alternatif C; Perbedaan itu fitrah, jadi perlu penangan yang berbeda untuk anak berkebutuhan khusus. Tidak bisa disamakan dalam satu wadah di kelas reguler 
Dari pengambilan tiga alternatif di atas, yakni Program A dan B sangat baik, tanpa merubah kebijakan yang sudah ada, namun akan mempunyai biaya finansial yang besar. Sedangkan Program C, merubah dan membuat kebijakan baru, bahwa ada pemisahan untuk penanganan yang lebih khusus, namun ini akan mengakibatkan dampak pertententangan dari berbagai sektor.

b) Rekomendasi Kebijakan

Dari pemaparan diatas bahwa pendidikan inklusi merupakan suatu konsep pendidikan yang bermuatan pada nilai kesetaraan hak serta kemanusian dalam kerangkan pendidikan untuk semua (education for all) dituangkan menjadi kebijakan melalui beberapa peraturan oleh pemerintah, khususnya pemerintah daerah. Model alternatif yang diambil adalah model alternatif A dengan rekomendasi penjabaran sebagai berikut:

1) Dinas pendidikan perlu melakukan koordinasi secara internal terutama dalam bidang tenaga pendidik yang dapat memahami konsep dan implementasi kebijakan inklusi pelatihan secara berkelanjutan.

2) Perlu waktu yang cukup lama untuk memberikan perubahan budaya dalam memandang perbedaan bahwa memang akan mempunyai kendala yang berat menyatukan dalam satu wadah antara anak berkebutuhan khusus dengan yang lain. Pendekatan secara politik oleh elite kepada masyarakat tentan pemahaman pendidikan inklusi memberikan pengaruh signifikan.

Sebaiknya dinas pendidikan memberikan penyuluhan secara berkala secara terus menerus dalam penyelenggaraan pendidikan inklusi.

\section{SIMPULAN DAN SARAN}

\section{A. Simpulan}

Berdasarkan pemaparan pada penelitian manajemen penyelenggaraan pendidikan inklusi pada lembaga pendidikan islam ini dapat disimpulkan bahwa pendidikan inklusi sebagai suatu sistem layanan ABK menyatu dalam layanan pendidikan formal, konsep ini menunjukkan hanya ada satu sistem pembelajaran dalam sekolah inklusi tetapi mampu mengakomudasi perbedaan kebutuhan belajar setiap individu, dalam Sistem persekolahan Nasional yang selama ini masih cenderung menerapakan layanan pembelajaran dengan "model ketuntasan hasil belajar bersama" melalui bentuk belajar klasikal berdampak kurang memberikan kefleksibelan penerapan pendidikan inklusi terutama bagi ABK dengan kondisi kemampuan mental rendah, pendidikan inklusi bagi anak berkebutuhan khusus belum dipahami sebagai upaya peningkatan kualitas layanan pendidikan, pendidikan inklusi cenderung dipersepsi sama dengan Sekolah biasa.

\section{B. Saran}

Pembahasan terkait penelitian kajian terhadap manajemen penyelenggaraan pendidikan inklusi pada lembaga pendidikan islam dalam penelitian ini masih sangat terbatas dan membutuhkan banyak masukan, dalam pelaksanaan pendidikan inklusi ada beberapa permasalahan dan kendala yang dihadapi dalam implementasinya, untuk itu diperlukan komitmen tinggi dan kerja keras melalui kolaborasi berbagai pihak baik pemerintah maupun masyarakat untuk mengatasinya, dengan demikian tujuan akhir dari semua upaya di atas yaitu kesejahteraan para penyandang cacat dalam memperoleh segala haknya sebagai warga Negara dapat direalisasikan secara cepat dan maksimal.

\section{DAFTAR RUJUKAN}

Agbayewa. (2011). Effect of homogenous and heterogeneous ability grouping class teaching on students interest, attitude and achievement in integrated science. International Journal of Psychology and Counselling, 3(3), 48-54.

Arifudin, O. (2020). Psikologi Pendidikan (Tinjauan Teori Dan Praktis). Bandung: Widina Bhakti Persada.

Arifudin, 0. (2021). Konsep Dasar Pendidikan Anak Usia Dini. Bandung: Widina Bhakti Persada Bandung.

Arifudin, O. (2019). Manajemen Sistem Penjaminan Mutu Internal (SPMI) Sebagai Upaya Meningkatkan Mutu Perguruan Tinggi. MEA (Manajemen, Ekonomi, \& Akuntansi), 3(1), 161-169.

Arifudin, O. (2018). Pengaruh Pelatihan Dan Motivasi Terhadap Produktivitas Kerja 
Tenaga Kependidikan STIT Rakeyan Santang Karawang. MEA (Manajemen, Ekonomi, \& Akuntansi), 2(3), 209-218.

Bahri, A. S. (2021). Pengantar Penelitian Pendidikan (Sebuah Tinjauan Teori dan Praktis). Bandung: Widina Bhakti Persada.

Bairizki, A. (2021). Manajemen Perubahan. Bandung : Widina Bhakti Persada.

Budiyanto. (2012). Modul Pelatihan Pendidikan Inklusif. Kementerian Pendidikan dan Kebudayaan Direktorat Jenderal Pendidikan Dasar, Direktorat Pembinaan Pendidikan Khusus dan Layanan Khusus Pendidikan Dasar.

Darsono. (2000). Belajar dan Pembelajaran. Semarang: IKIP Semarang Press.

Direktorat. (2007). Pedoman Umum Penyelenggaraan Pendidikan Inklusif. Jakarta: Direktorat Pendidikan Nasional.

Direktorat. (2008). Pengadaan dan pembinaan tenaga kependidikan dalam pendidikan inklusif. Direktorat Jenderal Manajemen Pendidikan Dasar dan Menengah Departemen Pendidikan Nasional.

Febrianty, F. (2020). Kepemimpinan \& Prilaku Organisasi Konsep Dan Perkembangan. Bandung: Widina Bhakti Persada.

Garnida. (2015). Pengantar Pendidikan Inklusif. Bandung: Refika Aditama.

Hanafiah, H. (2021). Pelatihan Software Mendeley Dalam Peningkatan Kualitas Artikel Ilmiah Bagi Mahasiswa. Jurnal Karya Abdi Masyarakat, 5(2), 213-220.

Hasbi, I. (2021). Administrasi Pendidikan (Tinjauan Teori Dan Praktik). Bandung: Widina Bhakti Persada.

Irwansyah, R. (2021). Perkembangan Peserta Didik. Bandung : Widina Bhakti Persada.

Juhji. (2020). Manajemen Humas Sekolah. Bandung: Widina Bhakti Persada.
Kustawan. (2013). Manajemen pendidikan inklusif. Jakarta: Luxima Metro Media.

Machali. (2010). Pengelolaan Pendidikan. Bandung: Pustaka Educa.

Mayasari, A. (2021). Implementasi Sistem Informasi Manajemen Akademik Berbasis Teknologi Informasi dalam Meningkatkan Mutu Pelayanan Pembelajaran di SMK. JIIPJurnal Ilmiah Ilmu Pendidikan, 4(5), 340345. https://doi.org/10.54371/jiip.v4i5.277

MINA. (2017). Anak Kebutuhan Khusus di Indonesia Capai 1,6 Juta. https://minanews.net/anakkebutuhankhusus-di-indonesia-capai16-juta.

Na'im, Z. (2021). Manajemen Pendidikan Islam. Bandung : Widina Bhakti Persada.

Nadeak, B. (2020). Manajemen Humas Pada Lembaga Pendidikan. Bandung: Widina Bhakti Persada.

Nasser, A. A. (2021). Sistem Penerimaan Siswa Baru Berbasis Web Dalam Meningkatkan Mutu Siswa Di Era Pandemi. Biormatika: Jurnal Ilmiah Fakultas Keguruan Dan Ilmu Pendidikan, 7(1), 100-109.

Rahayu, Y. N. (2020). Program Linier (Teori Dan Aplikasi). Bandung : Widina Bhakti Persada.

Sofyan, Y. (2020). Peranan Konseling Dosen Wali Dalam Meningkatkan Motivasi Belajar Mahasiswa Di Perguruan Tinggi Swasta Wilayah LLDIKTI IV. Jurnal Bimbingan Dan Konseling Islam, 10(2), 237-242.

Stubbs. (2002). Inclusive Education Where There Few Resources. Alih bahasa Susi Septaviana \& Didi Tarsidi. Bandung: Jurusan Pendidikan Luar Biasa, UPI.

Sugiyono. (2015). Metode Penelitian Pendidikan (Pendekatan Kuantitatif,. Kualitatif dan $R \& D)$. Bandung : CV. Alfabeta.

Sunardi. (2009). Pendidikan anak berkebutuhan khusus secara inklusif. Surakarta: FKIP UNS.

Tanjung, R. (2020). Pengaruh Penilaian Diri Dan Efikasi Diri Terhadap Kepuasan Kerja Serta 
Implikasinya Terhadap Kinerja Guru. Jurnal

Ilmiah MEA (Manajemen, Ekonomi, Dan Akuntansi), 4(1), 380-391.

Tarmansyah. (2007). Inklusi: Pendidikan Untuk Semua. Jakarta: Departemen Pendidikan dan Kebudayaan RI. 